\title{
The existing and the emerging: car ownership and car sharing on the road towards sustainable mobility
}

\author{
Elisabeth Marie Cassidy Svennevik \\ TIK Centre for Technology, Innovation and Culture, \\ Faculty of Social Sciences, \\ University of Oslo, \\ P.O. Box 1108, Blindern, 0317, \\ Moltke Moes vei 31, Eilert Sundts Building, \\ 0851, Oslo, Norway \\ Email: e.m.svennevik@tik.uio.no
}

\begin{abstract}
The use of car sharing has experienced rapid growth in recent years, but user-numbers are still low, and privately owned cars dominate. This paper studies how the use of car sharing contributes to altering the car system in urban areas. The study employs data from semi-structured interviews with 39 households in Oslo that are members of car-sharing arrangements. How does the current use of car sharing in Oslo relate to and influence the established use of privately owned cars? Are these relations elements in a transition towards sustainable mobility? The study finds that car sharing acts help to promote reduced car-ownership, changing and reducing the overall use of cars. However, there are limits to its contribution to environmental sustainability because of the continued use of fossil fuel cars and the continued dependence on privately used cars.
\end{abstract}

Keywords: car sharing; sustainability transition; shared mobility; collaborative consumption; privately owned cars; automotive industry.

Reference to this paper should be made as follows: Svennevik, E.M.C. (2019)

'The existing and the emerging: car ownership and car sharing on the road towards sustainable mobility', Int. J. Automotive Technology and Management, Vol. 19, Nos. 3/4, pp.281-300.

Biographical notes: Elisabeth Marie Cassidy Svennevik is a $\mathrm{PhD}$ student in Innovation Studies at TIK Centre for Technology, Innovation and Culture at the University of Oslo. Her main academic interest lies in the field of innovation studies, system change and sustainability transitions. The working title of her $\mathrm{PhD}$ is 'Changes towards sustainable mobility: experiences from car sharing in urban areas'. This research explores the changes in mobility focusing on how households use car sharing. The work is part of the research project tempest: transforming household mobility practices through shared consumption: low-carbon transport and sustainable energy solutions in urban areas. The project is funded by ENERGIX-Program at the Research Council of Norway.

This paper is a revised and expanded version of a paper entitled 'Connecting experimental processes and systemic change: the role of car sharing in a transition towards sustainable mobility' presented at 26th Gerpisa International Conference, Sao Paolo, 11-14 June 2018. 


\section{Introduction}

Achieving the transition to a low-carbon transport system is a key challenge today. New technologies for low-emission cars and electric vehicles (EVs) can assist in tackling some of the environmental challenges. However, to achieve the goals of sustainable mobility, more than technological change will be necessary (O'Brien and Sygna, 2013). Car sharing is important, because the new use of cars as shared goods through collaborative consumption can be part of a trajectory of changing frontiers in the automotive industry for sustainable mobility. Within this trajectory, we find new business models, new technologies and service innovations emerging from recent developments in share-economy concepts (Chevalier and Lantz, 2015; Tinnilä and Kallio, 2015). Although privately owned cars dominate personal transport today, this may shift as a consequence of changing behaviour and official policies on energy efficiency and pollution reduction (Lanzini, 2018). At the same time, car sharing is gaining momentum worldwide (Lindloff et al., 2014; Shaheen and Cohen, 2013).

Car sharing plays a role in the urban transport system by de-privatising the car (e.g., Banister, 2008; Botsman and Rogers, 2010; Degirmenci et al., 2017; Urry, 2004). Several studies indicate that car sharing helps to promote environmental sustainability (Firnkorn and Müller, 2011; Frenken and Schor, 2017; Hildermeier and Villareal, 2014; Meijkamp, 1998; Rabbitt and Ghosh, 2016), whereas others argue that if the sharing economy follows the pathway of continued consumption, this is unlikely to drive a transition towards sustainability (Martin, 2016). Other studies point out that efforts to achieve sustainable mobility take various forms, as when abstract concepts of sustainable mobility are adopted in local contexts and shaped by local actor constellations (Berger et al., 2014). A recent study indicates that the sustainability implications of car sharing depend on where such sharing systems are perceived to be in the urban transport agenda (Akyelken et al., 2018).

This implies that use of new services from the sharing economy plays a role for sustainability. However, research is ambiguous on how car sharing is emerging in relation to the privately owned car, and how this plays a role in a transition towards sustainable mobility. The role of the use of car-sharing services has attracted growing attention (Bergman et al., 2017; Dowling et al., 2018; Kent et al., 2017; Kent and Dowling, 2016, 2018; Sovacool and Axsen, 2018; Truffer, 2003; Vervaeke and Calabrese, 2015), but research on households' use of car sharing in urban areas is still limited. Car sharing appears to play a role in sustainable urban mobility; however, there is little research on how this is involved in changing the established dominance of privately owned cars. This article investigates the matter further, by examining the relationship between the emerging household use of car sharing and the existing use of privately owned cars, and the consequences as regards to achieving sustainable mobility. No study has until now addressed this specifically. Drawing on empirical evidence, I show how household use of car sharing emerges in relation to the dominance of privately owned cars, and how this can be part of a shift towards sustainable mobility.

I investigate these dynamics by analysing to what extent the emerging use of car sharing destabilises the dominant regime and reduces the dominance of privately owned vehicles. Empirically, the study explores how households in urban areas of Oslo use car sharing, and how this use relates to the established dominance privately owned cars.

The number of members and users of car-sharing arrangements has increased in recent years. At the end of 2017, Bilkollektivet ('collective member-ownership of cars') 
had around 6,000 members and a fleet of 300 cars, available in approximately 100 locations in Oslo. Hertz Bilpool (part of a car rental business) has a fleet of some 100 cars and 2,800 members in Oslo. Nabobil (lit.: neighbour-car: platform of privately owned cars) reports has more than 170,000 registered users and 5,500 vehicles throughout Norway (George and Julsrud, 2018). Although they have many registered members, not all are active users, but there has definitely been a growth in members and actual users. Nabobil reports that cars from their service were used 33,000 times in Norway in one year, and that use increased by $150 \%$ and registered membership by $110 \%$ from 2016 to 2017 (Tobiassen, 2017).

Private car use in Oslo is changing. Recent years have brought changes in special regulations for private car use and new regulations favouring EVs. The focus has been on EVs for sustainable mobility: the positive environmental effects of EVs are taken for granted, because some $96 \%$ of all electricity in Norway is produced from renewable sources (Figenbaum et al., 2015). Other new policies include restrictions on free parking and the introduction of residential parking regulations. Parking is regulated by the local authorities, and parking regulations affect land-use and transport, privately owned cars in particular (Christiansen et al., 2017). There are special regulations for EVs and diesel cars, road tolls and toll differentiation for rush hours, but few policies on car sharing. There are ongoing political processes with, inter alia, proposals for changing the parking regulations for new dwellings, with a reduction in the minimum norm for parking lots if there are areas set aside for car sharing (Oslo kommune ved Plan-og bygningsetaten, 2015). The Oslo municipal government has stated that it wants to facilitate further opportunities for car sharing by means of new parking norms. However, the plans for car sharing are sketchy: it is unclear what type of services and what other regulations are involved.

This paper is organised in four parts. The introduction presents the background of previous research and the need for this research, the contributions of this study and its theoretical framework. Second, the methodology and data collection are presented, as is the research design. Third, the results are presented and the findings discussed. Fourth, the conclusion and implications are presented, and limitations of this study assessed.

\subsection{Theoretical framework}

\subsubsection{Forms of reconfiguration}

To investigate how the niche of car sharing interacts with the regime of privately owned cars, this analysis applies parts of a preliminary framework on forms of reconfiguration proposed by Hodson et al. (2017). These recently developed concepts concern the relations between the use of niche innovations such as car sharing, and an existing regime such as the dominance of car owning. This conceptualisation posits three approaches to analysing these relationships: as competing, complementary and co-existing (Hodson et al., 2017). The competing form examines struggles between new vs. new or new vs. old socio-technical arrangements, the complementary focuses on productively fused relationships of new and new/old socio-technical arrangements, and the co-existing looks at parallel and largely independent socio-technical arrangements.

The concept of system reconfiguration creates an approach that enables study of how interactions between multiple social, organisational and technical innovations can change entire systems. This paper applies concepts from the reconfiguration pathway to explain 
sustainability transitions (see Geels and Schot, 2007) and concepts of forms of reconfiguration (Hodson et al., 2017). While some research has focused on the substitution pattern, for example how EVs can replace fossil fuel cars, scholars have increasingly developed alternative transition pathways (Berggren et al., 2015; Geels et al., 2016; Geels and Schot, 2007; Hodson et al., 2017; Köhler et al., 2017).

Regarding sustainability transitions, the multi-level perspective MLP (Geels, 2011, 2012) holds that although each transition is unique, the general dynamic is that transitions come about through interactions between processes at three levels: niches, regime and landscape. Simply put, the established use of privately owned cars can be seen as the dominant regime, the novelty of car-sharing services as niches, and environmental concerns as landscape pressure. Niche innovations gradually build up internal momentum, the regime destabilises because of cracks and tensions and creates windows of opportunity for wider diffusion of niche-innovations, and the landscape level with exogenous changes creates pressures on the regime (Geels, 2015). For analytical purposes, I assume here that the regime consists of private car ownership. This is a simplification; one could also see the regime as including private transport by other means than cars. Further, my analysis treats landscape pressures as exogenous, so there is no further investigation of these dynamics here.

Figure 1 Reconfiguration pathway (see online version for colours)

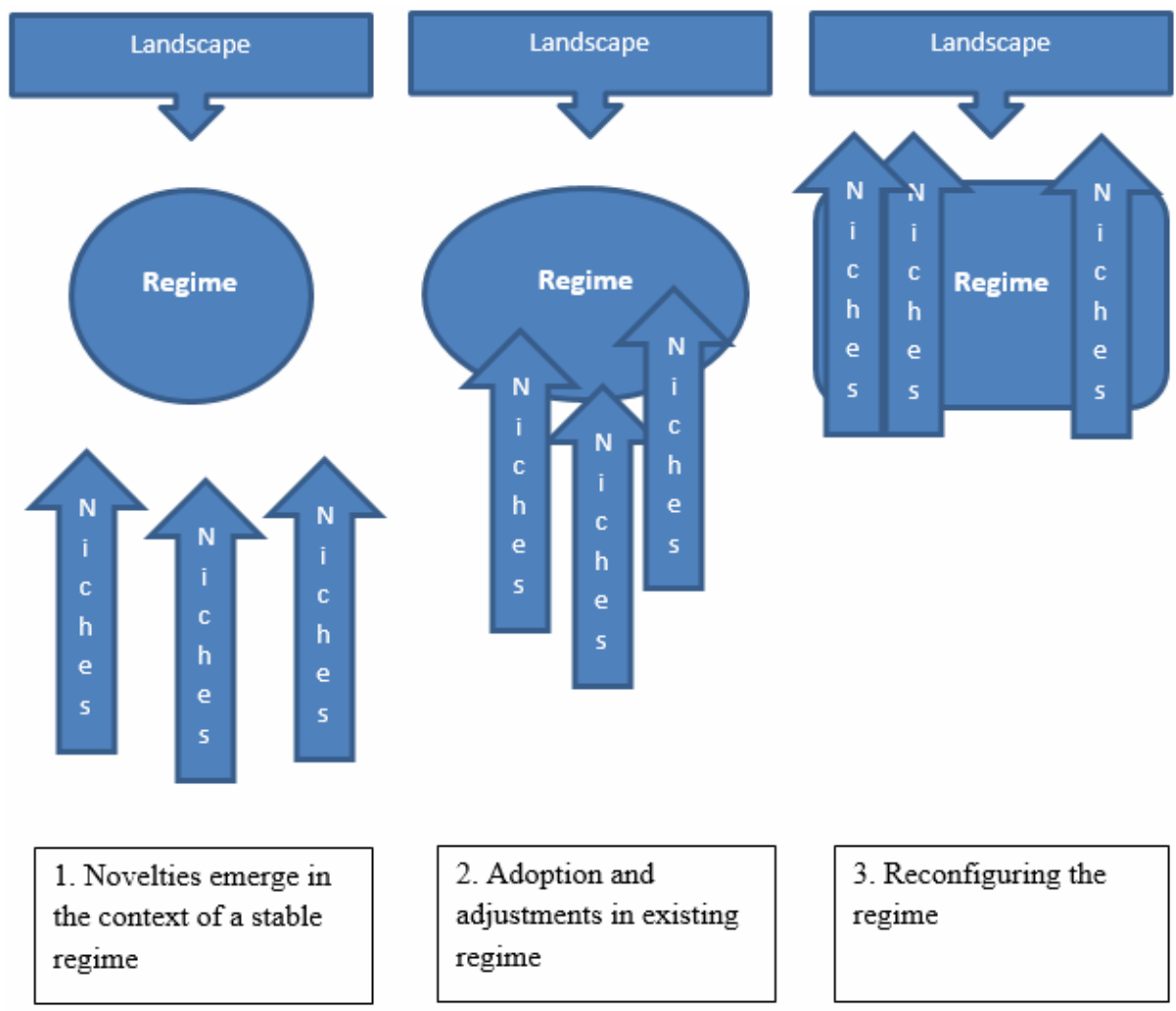

Source: Based on Geels and Schot (2007) 
Criticised for the MLP's hierarchal understanding and how it treats landscape pressure as exogenous, scholars have continued to develop this perspective by incorporating changes (Geels, 2011). The MLP has thus evolved into several strains of research - such as how to understand niche development (Nykvist and Whitmarsh, 2008), niches in protective spaces and the role of policy (Raven et al., 2016), niche regime interaction (Bui et al., 2016; Dijk, 2014), and inclusion of landscape pressures (Næss and Vogel, 2012).

The reconfiguration pathway focuses on regime-niche interaction, and how niches are involved in causing instability in a regime, and the consequences of this. Geels and Schot (2007) have examined how these dynamics emerge. First, they explain the role of the local niches, how these are initially adopted in the regime to solve local problems and subsequently trigger further adjustments in the basic architecture of the regime. Second, the use and diffusion of a novelty may lead to technical changes or changes in user practices and perceptions, creating space for new adoptions of niche-innovations. Third, regime actors may survive in the reconfiguration path, but competition and tensions occur among component suppliers. Figure 1 illustrates the reconfiguration pathway in simplified form.

The sustainability transition discipline originally focused on changes of entire systems (Elzen et al., 2004a, 2004b; Geels, 2002, 2004). Sustainability transitions involve interactions between technology, policy/power/politics, business/markets, and culture/ discourse/public opinion; socio-technical systems thus consist of artefacts, knowledge, capital, labour, cultural meaning, etc. (Geels, 2004). Recent work has focused more on how innovations interfere with existing systems (Geels, 2017; Geels et al., 2016, 2015; Hodson et al., 2017).

These concepts set the stage for two key issues in this paper. First, this approach focuses mainly on environmental sustainability, and is not applied for solving wider socio-economic problems. Second, the approach accepts that 'green' innovations or practices should be not only environmentally sustainable, but economically viable and socially acceptable as well.

Concepts from this literature can be applied in studying dynamic interactions between the use of car sharing and privately owned cars (Farla et al., 2012; Geels, 2012; Loorbach et al., 2017; Markard et al., 2012; Temenos et al., 2017). These interactions can be studied as a socio-technical system because such a system sees the use of the car distribution as a social arrangement, and the cars and booking systems as technological artefacts (Truffer et al., 2017). The present article investigates how the use of car sharing by urban households offers possibilities for changing the current car system on a city scale, and in what ways. This then leads to a discussion on car sharing as part of a sustainable transition of the car system. I address the research questions: how does the use of car sharing in Oslo today relate to and influence the established use of privately owned cars? Are these relations part of a transition towards sustainable mobility?

\section{Methodology}

\subsection{Context}

The use of car sharing in Oslo was chosen for this study because it enables examination of place-specific use of car sharing, and because of the growing number of users of various car-sharing services in the area. Oslo is undergoing changes in regulations, 
markets, technologies and infrastructure concerning the use of private cars, and this creates a need to investigate the issues of private car use in the area. Households are the study objects because the concerns using cars and other transportation means are often handled within a social group such as a family or a household. Changes of household locations, members, and daily- and free time activities influence how household members interact and use transportation.

\subsection{Data collection}

The data for this study consist of 39 semi-structured interviews with households in urban areas of Oslo. These households are registered members of the following car-sharing services: 'Nabobil', 'Hertz BilPool' and 'Bilkollektivet'. Nabobil is a peer-to-peer (P2P) car-sharing service that does not have its own fleet of cars: it is an online platform that organises car sharing between private persons. Its online fleet consists of cars that members register for sharing. 'Bilkollektivet' is a business-to-consumer (B2C) service, with a car fleet available for its customers. It is a cooperative enterprise: members own the company, and any surplus profits return to the company. Also 'Hertz BilPool' is a B2C service, with a car fleet available for its customers. However, it is a corporate company owned by the car rental company Hertz.

Table 1 Overview of data collection

\begin{tabular}{lccccc}
\hline Name of car-sharing company & Type of car-sharing company & \multicolumn{5}{c}{ Household interview \# } \\
\hline Bilkollektivet & B2C cooperative & 1 & 8 & 9 & 13 \\
$>$ 6,000 registered members & Business to consumer & 15 & 16 & 20 & 22 \\
$>300$ cars available & & 23 & 25 & 26 & 27 \\
& & 29 & 30 & 36 & 37 \\
& & 38 & 39 & & \\
& & & & & \\
Hertz Bilpool & B2C corporate & 4 & 5 & 6 & 7 \\
$>2,400$ registered members & Business to consumer & 14 & 17 & 21 & 31 \\
$>135$ cars available & & 33 & 34 & 35 & \\
Nabobil & P2P & 2 & 3 & 10 & 11 \\
$>170,000$ registered members & Peer-to-peer & 12 & 18 & 19 & 24 \\
$>5,000$ cars available & & 28 & 32 & & \\
\hline
\end{tabular}

The need for interviewees was announced through the research project on the Facebook pages of the three suppliers of car sharing. An overview of possible participants was made, and interviews was then booked with various types of households of couples or singles in families with and without children. Thirty-three of the households were using cars in various ways from the car sharing services, two were members providing cars and four were members but non-users. Two different interview-guides for users and non-users were developed. The guides include an outline of the topics (Kvale, 2007) with suggested questions on life situation, daily travel, leisure travel, motivation for using car sharing, and other elements like the role of policies and regulations on transportation, and implications of use. Table 1 gives an overview of the household interviews, categorised by numbering of the households (used throughout this paper), the car-sharing companies 
they use and the type of company (P2P, B2C). With colleagues from the research project, I conducted the semi-structured interviews in the homes of the respondents during three periods: May-July 2017, October-November 2017 and January-March 2018. I was present in 34 interviews and they lasted from 45 minutes to two hours. The households were rewarded a gift card of $500 \mathrm{NOK}$ for participating.

By conducting the semi-structured interviews in their own home, it enabled the possibilities to get personal and thorough descriptions. The participants also showed me around and pointed out distance to parking, bus station, schools, grocery store etc. In addition, I saw the different apartment arrangements, parking, gardens, common areas, lift facilities, playgrounds etc. Although I did not take pictures or video recorded this, I took notes and it created a greater understanding about the content in the interviews.

There are several benefits of collecting the data like this, as I got rich descriptions of the households' practical experience with using car sharing. I caught their thoughts and their reasons for using it, their opinions on how they think car sharing is functioning for them and what challenges they are facing. However, this data collection also has limitations and biases due to the self-selection in the sample. Although we informed the interviews about the confidentiality and purpose of the research, there can also be a risk that the interviewees will not share everything and choose what they will talk about and what they will not tell. For example, one informant talked about travelling without security equipment for the child, and the other household participant expressed not remembering this and did not want to talk more about it in the interview.

\subsection{Analysis}

The research strategy for this data analysis involved three main steps. First, all interviews were transcribed; then memos, audios and transcriptions were organised in Nvivo. Second, these were coded (Miles et al., 2013) and memos of preliminary findings and research questions were written. This part was done several times, and earlier versions focused on the dynamics of experimentation and multiplicity due to urban change and new use of several transportation means. When the analysis further had to be more focused, the study was concentrated towards car sharing and car owning. Dynamics between the use of the services and the existing system of privately owned cars were then identified and organised. This part of the analysis was exploratory, mapping out the various use of the services found in the sample without following concepts from the literature. Memos on these processes were made, sorting out recurrent patterns and social mechanisms. Third, these processes were further analysed and systematised following the forms of reconfigurations; complementary, competing or co-existing. This step of the analysis was more explanatory, using the concepts to explain the dynamics between car owning and car sharing in the particular usages found in the sample. The qualitative study was designed for confirmability and transparency (Creswell and Miller, 2000; Yilmaz, 2013) and to safeguard ethical concerns and respondent anonymity (Yin, 2010).

\section{Findings}

First, I present the relationships between the new and the established. Here the analysis shows whether the use of car-sharing produces competing, co-existing or complementary 
forms of reconfiguration. Second, I explain how these concepts are inadequate for explaining all aspects of use, and note some additional findings. Third, I discuss the findings and what these relationships imply, and the role of car sharing in promoting a transition towards sustainable mobility. I also present two paradoxes revealed by this study.

\subsection{Relationship between the new and the established}

The concepts of forms of reconfiguration can help to explain some of the dynamics in relations between the emerging use of car sharing and the existing dominance of privately owned cars.

Table 2 gives an overview of the results, and displays the data from the sample.

Table 2 Overview of findings

\begin{tabular}{|c|c|c|c|c|}
\hline $\begin{array}{l}\text { Form of } \\
\text { reconfiguration }\end{array}$ & Relationship & Empirical findings & $\begin{array}{l}\text { Provides } \\
\text { potential }\end{array}$ & $\begin{array}{c}\text { Data } \\
\text { household \# }\end{array}$ \\
\hline Complementary & $\begin{array}{l}\text { Productively fused } \\
\text { relationships of new and } \\
\text { new/old socio-technical } \\
\text { arrangements }\end{array}$ & $\begin{array}{c}\text { P2P } \\
\text { Cars are the same, and } \\
\text { rely on privately } \\
\text { owned cars }\end{array}$ & $\begin{array}{l}\text { Potential for } \\
\text { reduction }\end{array}$ & $\begin{array}{l}3,10,12,28, \\
11,18,24,32\end{array}$ \\
\hline Competing & $\begin{array}{l}\text { Struggles between new } \\
\text { vs. new or new vs. old } \\
\text { socio-technical } \\
\text { arrangements }\end{array}$ & $\begin{array}{c}\text { B2C } \\
\text { Car sharing located } \\
\text { near housing, w/range } \\
\text { of cars }\end{array}$ & $\begin{array}{l}\text { Potential for } \\
\text { replacing }\end{array}$ & $\begin{array}{c}06,07,13, \\
16,23,26,38\end{array}$ \\
\hline Co-existing & $\begin{array}{l}\text { Parallel and largely } \\
\text { independent } \\
\text { socio-technical } \\
\text { arrangements }\end{array}$ & $\begin{array}{l}\text { B2C } \\
\text { Car sharing in addition } \\
\text { to privately owned car, } \\
\text { such as EV }\end{array}$ & $\begin{array}{l}\text { Potential for } \\
\text { recombining }\end{array}$ & $02,04,08,14$ \\
\hline
\end{tabular}

\subsubsection{Competing form of reconfiguration}

Several households (\#06, \#07, \#13, \#16, \#23, \#26, \#38), say they are so satisfied with using car sharing that they did not want or need to own a car. Two households, (\#13, and \#07) had even been offered cars by their families, but chose not to accept. They did not want to own a car even though they would not have to buy it, and felt that car sharing was a better option for them. As one respondent put it:

\footnotetext{
"It is the reassurance of knowing that there is always a car that we can use. It is the security aspect. We had cars for a long time; before the car collective, we both had a car for 10 years, my wife had a car and I had one. I did not want to lose the feeling of being able to drive where I want, whenever I want. The car collective became a substitute. It gives me the chance to be impulsive and just drive off." (\#16)
}

The competing form of reconfiguration can explain this relationship between the new use and the established system. Households have constant access to a range of cars, located near where they live. This involves the use of both $\mathrm{B} 2 \mathrm{C}$ cooperative and $\mathrm{B} 2 \mathrm{C}$ corporate. Households use a range of different car types for longer trips out of town and for shorter errands in the neighbourhood - smaller and larger vehicles, but mostly fossil fuel cars. 
Only a very few of the locations for cars from the B2C services offered EVs, and most of the household stated that they did not use EVs from these car sharing companies.

With this supply of diverse types of vehicles, car sharing covers both material and emotional goods in a way satisfactory for some households, who find car ownership neither necessary nor desirable. This indicates that some use of car sharing in cities can have the potential to replace the established regime of car ownership. However, this is the case only for certain households, and does not mean that the whole regime of privately owned cars can be replaced.

\subsubsection{Co-existing form of reconfiguration}

Some households use car sharing in addition to a privately owned, smaller EV. The latter is used for daily travels, and car sharing for longer trips or if a larger vehicle is needed (\#02, \#04, \#08). These respondents explain that, because of new technology and the new policies in Oslo, they want to own an EV instead of a fossil fuel car. New regulations such as tax reductions and free parking for EVs creates strong incentives. In addition, some mentioned that they considered it important to use a more environmentally friendly means of transport than a fossil fuel car (\#02,\#08).

The co-existing form of reconfiguration can explain the relationship when the use of car sharing is a supplement to the use of privately owned cars. Because the smaller EVs cannot solve family transport needs for all activities throughout the year, car sharing is used on those occasions when another type of vehicle is needed. Car sharing makes it possible to have an EV instead of owning a larger fossil fuel car. This reduces the use of fossil fuel cars and means fewer emissions from using unnecessarily large vehicles for daily transport.

This resembles car rental services: some households refer to it as self-service car rental (\#08). Car sharing does not replace the privately owned car. This shows that there is potential for recombining the system of privately owned vehicles. The current regime of private ownership can shift towards greater use of EVs; further changes may involve charging infrastructure, development of battery technology etc. The regime may remain stable, given the continued need to use a private vehicle for everyday trips. Ultimately, it shows that there will be a continued occasional need for larger cars: a need for different types of vehicles from car-sharing services, and from the car manufacturing industry as well.

\subsubsection{Complementary form of reconfiguration}

Households \#03, \#10, \#12 and \#28 use the P2P car-sharing service called Nabobil. One household, \#19, had used P2P only once, when it was impossible to use public transport to attend an arrangement in a rural area. Some households (e.g., \# 32) use P2P car sharing in addition to other car-sharing services. Those who provide vehicles in this service may be neighbours who want to earn money from their privately owned car, or people who invest in a car in order to rent it out. Three households provided a car for sharing: \#11, \#18 and \#24. Despite some differences, all users of the P2P service said that they relied on the existence of privately owned cars.

The complementary form of reconfiguration can explain the form of relationship between the use of $\mathrm{P} 2 \mathrm{P}$ car sharing and the regime of privately owned cars. This is because of how it involves a productively fused relationship between new and old 
socio-technical arrangements. P2P car sharing can exist only in combination with private car ownership. The niche of this type of car sharing requires other private car owners who can provides vehicles. Users of the P2P car sharing use the same cars that exist in the regime. However, they have made adjustments in user practices, such as booking, picking up and delivering the cars.

The complementary form of reconfiguration can thus explain how the niche can reconfigure the regime, because the cars are the same in the niches as in the regimes. The differences lie not in the cars as such, but in user practices and business models for providing the cars. This form of reconfiguration offers a potential for reducing private car ownership. P2P car sharing involves using cars that already exist, and these vehicles are used more frequently and by more people.

\subsection{Discussion}

\subsubsection{Using cars vs. owning}

A major explanation cited by respondents was that the need to use cars for everyday trips has either been reduced or become redundant. However, the reasons why cars are not needed for everyday uses vary. In some cases, it has to do with recent housing complexes in new urban areas near to grocery shops, preschool and school facilities, bus stops and/or a metro station. The $\mathrm{B} 2 \mathrm{C}$ cooperative may have parking lots within the housing complex. Household \#06, \#08, \#09, \#13, \#26 and \#27 have B2C close to their homes. Other households \#07 and \#16 have started to use carriage bicycles or electric bicycles that can transport both children and goods. Others use traditional bicycles and walking, in addition to public transport. Some use delivery services for groceries, and shop online for clothes, furniture, electrical items, etc. This means less need to use a car for regular errands. The interaction between the various means of transport and the location of the household is important to how these families use car sharing.

Despite the differences in use, there are similarities that show how households who use car sharing do not need to own a vehicle in order to use one. Therefore, I hold that the niches of car sharing also contribute to stabilising the regime. Accessing cars, instead of owning them, causes changes in user practices and business models - but, because households still want to use cars privately, the regime is stabilised. The occasional use of private cars instead of ownership reconfigures the regime of privately owned cars, making it a matter of the use of cars instead of owning them. Car usage in urban areas is changing: car sharing reduces the frequency of car use and the need to own a car. In this way, car sharing causes de-stability of the private ownership regime. However, car sharing also contributes to maintaining the current use of and dependency on privately used cars, thereby helping to stabilise the regime as well. Figure 2 shows how the regime changes from privately owned to privately used cars.

The availability of other means of transport for daily trips (public transport, bicycles, walking) and urban housing (shorter distances) may create a demand for private cars occasionally rather than on a daily basis, and car sharing may cover this need. This also implies a vice-versa situation; when car sharing is available, this creates an important reason for not having to own a car. Car sharing provides vehicles for occasional use, and this is what households need. What many urban households require is not a car for everyday use, but access to a car. When everyday travels can be managed without owning a car, and car sharing is available, the privately owned car is simply not necessary. In this 
way, car sharing together with the reduction in cars for everyday travel affects the regime of privately owned cars.

Figure 2 Reconfiguring the private-car regime (see online version for colours)
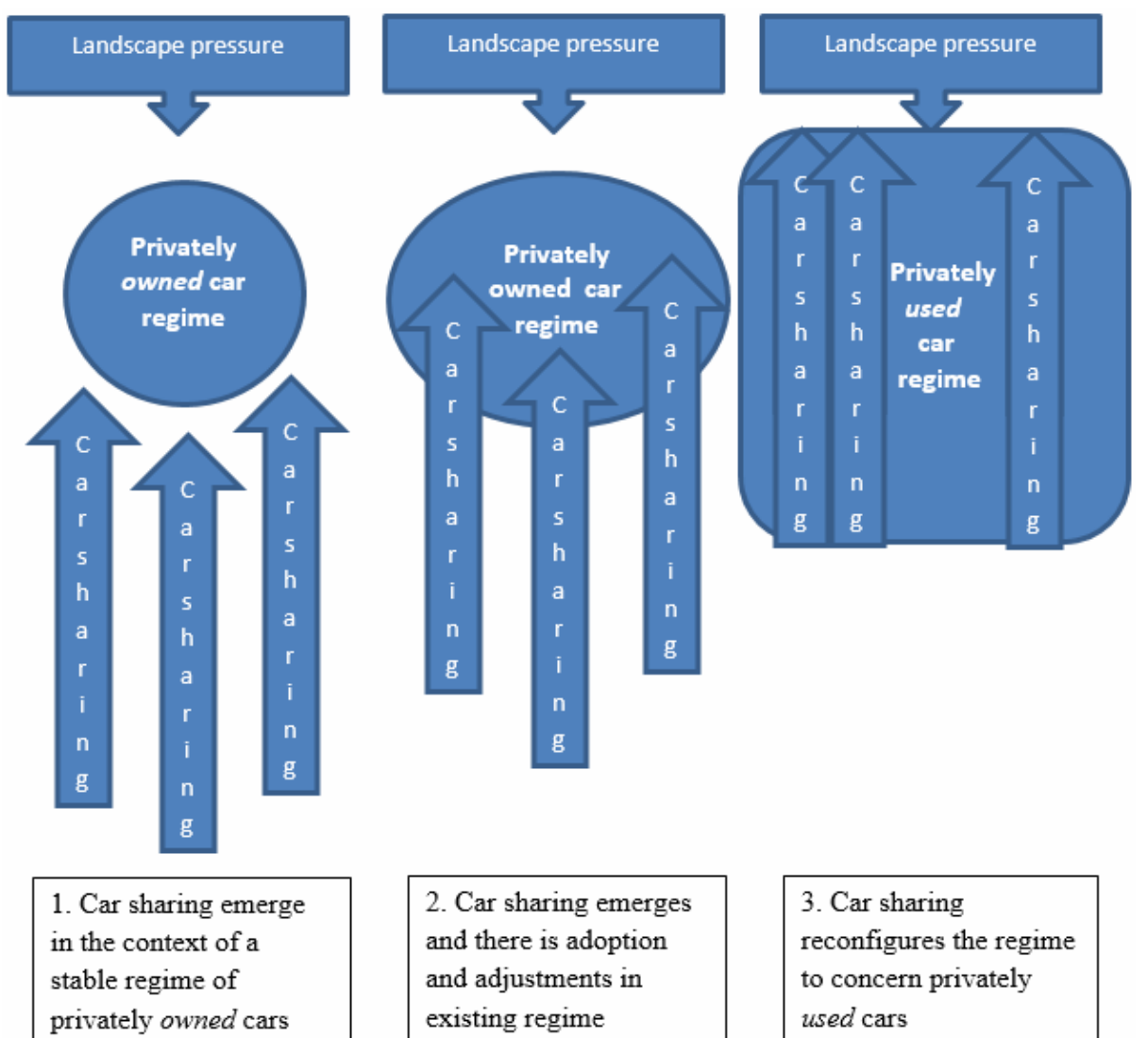

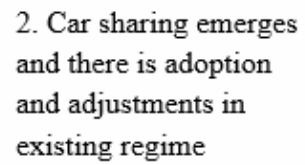

\section{Car sharing} reconfigures the regime to concern privately used cars

Source: Based on Geels and Schot (2007)

\subsubsection{Environmentally sustainable mobility}

The forms of reconfiguration on how the use of niches affects the stable regime give reason for critical reflection on the role of car sharing in achieving the transition towards a low-carbon society. Some aspects contribute to such a transition because of new opportunities for choosing a vehicle for specific purposes, instead of owning one or two cars, and the reduced use of cars. All respondent households that used to own a car say that they use cars less when they use car sharing instead of owning. Other aspects, however, do not promote the transition towards sustainability, because of the use of fossil fuel vehicles for car sharing, and the use of cars instead of public transport, walking or bicycling. Respondents noted difficulties in assessing EVs and obstacles to getting EVs through sharing services.

Contributing to environmental sustainability, there is also the possibility to differentiate, using cars for specific occasions. As noted by household \#32, it is no longer 
necessary to own an 'omni-purpose' or 'worst-case scenario' car. The household can select vehicles in the car-sharing services for the specific purposes of each trip. Car-share vehicles are also newer, which can mean lower emissions than with older, privately owned models. Importantly, the availability of cars for occasional use emerges as a decisive factor when households evaluate whether they need to own a car, and thus functions as an enabler for reducing car ownership. Moreover, those who need a vehicle for everyday use can own a smaller EV; the availability of car-sharing facilitates this.

On the other hand, the still-widespread use of fossil fuel cars does not contribute to environmental sustainability. At present, the car-sharing services in the sample provide mostly fossil fuel cars, and car sharing means continued private household use of cars. The use of EV in car sharing is still low - only a few households in the sample report having used EVs (\#07, \#06). They note the limited selection of EVs as well as the limited spread of charging facilities and lower predictability because of uncertainties about battery capacity. In addition, car sharing is still for private use. It does not involve using other alternatives, such as carpooling or bicycling, or reducing trips with changes in urban settings or home office options and thus does not mean a transition away from the use of cars in private settings.

\subsubsection{Paradoxes in Oslo}

From the use of car sharing reported by the households sampled, two paradoxes emerge regarding the role of car sharing for sustainable mobility. First, for these households, car sharing involves almost no use of EVs. This may be partly because the car-share services chosen for this study - Nabobil, Hertz BilPool and Bilkollektivet - have few EVs in their fleets. There exist other car-sharing services, like the company called Movebout, that offer only EVs. However, this study has shown that the household use of car sharing involves fossil fuel cars. This can be seen as a paradox for sustainable mobility in Oslo, because Oslo has become a world leader in the growth in EV ownership. A second paradox is that when car-sharing services are available in their areas, households that normally would not have used private cars now get the possibility to use cars - and that may result in greater use of private cars instead of other, more environmentally sustainable options.

\section{Conclusions and implications}

The niche of car sharing affects the regime of privately owned cars. First, the analysis here offers examples of the use of car sharing and explains how three forms of reconfigurations can explain the relationship between the new and the established. Second, the discussion shows what these relationships imply, and offers a critical evaluation of the role of car sharing in achieving the transition towards sustainable mobility.

The competing form of reconfiguration involves the use of $\mathrm{B} 2 \mathrm{C}$ cooperative and B2C corporate, where the households are satisfied with using car sharing and do not want or need to own a car themselves. This shows that car sharing has the potential to replace the established regime of private car ownership, substantially reducing the total number of privately owned cars. The co-existing form of reconfiguration can define the relationship when car sharing is used as a supplement to the use of privately owned cars. 
This relationship offers the possibilities of recombining the system of private car ownership, by making it possible to own smaller cars for everyday use, and then opting for specific other types of cars through occasional car sharing. The complementary form of reconfiguration can explain how P2P car sharing needs the established system of private car ownership in order to exist, and thus represents a new fusion between old and new socio-technical arrangements. This offers the potential of reducing the established system of private car ownership.

These relationships imply that, with the current forms of reconfiguration, car sharing acts as a facilitator for reducing car-ownership and reduces the general use of private cars. However, the contribution to a sustainability transition is limited because of the continued use of fossil fuel cars and of privately used cars.

According to the theory of reconfiguration pathways, niches contribute to instability in a regime. Niches initially adopted to solve local problems subsequently trigger further adjustments in the basic architecture of the regime, in turn leading to technical changes or changes in user practices and perceptions, and may create space for new adoption of niche-innovations (Geels and Schot, 2007). This research study supports that theory, as the household use of private cars has persisted, with adjustments in user practices and within the distribution and markets concerned. The analysis has revealed some patterns in how car sharing is an element in changing today's established car system, dominated by private car ownership. There remains a need for private cars - but for occasional instead of daily use. The point is to be able to use cars, without necessarily owning them.

\subsection{Limitations and suggestions}

The limitations of this study concern the choice of theoretical framework, the choice of data collection, as well as the analytical process. The study has focused only on household use today, in urban areas of Oslo, and on sharing vs. owning cars. It has drawn solely on the theory of sustainability transition and forms of reconfiguration, which entails limitations for studying the mobility system and system changes. Further, the study is mainly a snapshot of a co-evolution, or a moment on the pathway of reconfiguration. The analysis does not grasp the dynamics of change over time. In addition, the concepts employed were originally formulated for studying experimental process, multiplicity and changes at city level, taking into account a wider range of analytical areas. Further research is indicated, using empirical data on the current system. Other relevant actors could be included, e.g., policy, markets and infrastructure. And finally, further research is needed on the use of EVs and car sharing.

\section{Acknowledgements}

This research is part of the TEMPEST project (TEMPEST: transforming household mobility practices through shared consumption: low-carbon transport and sustainable energy solutions in urban areas) funded by Research Council of Norway under ENERGIX Project No. 255430. I am grateful to Nina Thune-Larsen for assistance with booking and transcribing the interviews, to Cyriac George for work with the pilot study and one interview, and to Tom Erik Julsrud and Eivind Farstad for work with data collection. I also wish to thank the households who participated in this research. 
An earlier version of this paper was presented at the Gerpisa Colloquium in São Paulo, Brazil, in June 2018. I am grateful for comments from this conference, and from two anonymous reviewers, as well as for comments on this research from attending the TIK PhD seminar at the University of Oslo in May 2018 and the ETH PhD Academy on Sustainability and Technology at ETH Zürich, Switzerland, June 2018.

\section{References}

Akyelken, N., Banister, D. and Givoni, M. (2018) 'The sustainability of shared mobility in London: the dilemma for governance', Sustainability, Vol. 10, No. 2, p.420, DOI: https://doi.org/ $10.3390 / \mathrm{su} 10020420$.

Banister, D. (2008) 'The sustainable mobility paradigm', Transport Policy, Vol. 15, No. 2, pp.73-80, DOI: https://doi.org/10.1016/j.tranpol.2007.10.005.

Berger, G., Feindt, P.H., Holden, E. and Rubik, F. (2014) 'Sustainable mobility - challenges for a complex transition', Journal of Environmental Policy \& Planning, Vol. 16, No. 3, pp.303-320, DOI: 10.1080/1523908X.2014.954077.

Berggren, C., Magnusson, T. and Sushandoyo, D. (2015) 'Transition pathways revisited: established firms as multi-level actors in the heavy vehicle industry', Research Policy, Vol. 44, No. 5, pp.1017-1028, DOI: https://doi.org/10.1016/j.respol.2014.11.009.

Bergman, N., Schwanen, T. and Sovacool, B.K. (2017) 'Imagined people, behaviour and future mobility: insights from visions of electric vehicles and car clubs in the United Kingdom', Transport Policy, Vol. 59, pp.165-173, DOI: https://doi.org/10.1016/j.tranpol.2017.07.016.

Botsman, R. and Rogers, R. (2010) What is Mine is Yours: the Rise of Collaborative Consumption, Harper Business, New York.

Bui, S., Cardona, A., Lamine, C. and Cerf, M. (2016) 'Sustainability transitions: insights on processes of niche-regime interaction and regime reconfiguration in agri-food systems', Journal of Rural Studies, Vol. 48, pp.92-103, DOI: https://doi.org/10.1016/j.jrurstud.2016. 10.003 .

Chevalier, A. and Lantz, F. (2015) 'Personal car or shared car? Predicting potential modal shifts from multinomial logit models and bootstrap confidence intervals', International Journal of Automotive Technology and Management, Vol. 15, No. 2, pp.149-170, DOI: https://doi.org/ 10.1504/IJATM.2015.068549.

Christiansen, P., Engebretsen, Ø., Fearnley, N. and Hanssen, J.U. (2017) 'Parking facilities and the built environment: impacts on travel behaviour', Transportation Research Part A: Policy and Practice, Vol. 95, pp.198-206, DOI: https://doi.org/10.1016/j.tra.2016.10.025.

Creswell, J.W. and Miller, D.L. (2000) 'Determining validity in qualitative inquiry', Theory into Practice, Vol. 39, No. 3, pp.124-130, DOI: https://doi.org/10.1207/s15430421tip3903_2.

Degirmenci, K., Lapin, S. and Breitner, M.H. (2017) 'Critical success factors of carsharing and electric carsharing: findings from expert interviews in continental Europe', International Journal of Automotive Technology and Management, Vol. 17, No. 3, pp.294-315, DOI: https://doi.org/10.1504/IJATM.2017.086413.

Dijk, M. (2014) 'A socio-technical perspective on the electrification of the automobile: niche and regime interaction', International Journal of Automotive Technology, Vol. 14, No. 2, pp.158-171.

Dowling, R., Maalsen, S. and Kent, J.L. (2018) 'Sharing as sociomaterial practice: car sharing and the material reconstitution of automobility', Geoforum, Vol. 88, pp.10-16, DOI: https://doi.org/10.1016/j.geoforum.2017.11.004.

Elzen, B., Geels, F.W. and Green, K. (2004a) System Innovation and the Transition to Sustainability: Theory, Evidence and Policy, Edward Elgar Publishing, Incorporated, Cheltenham, UK/Northampton, MA, USA. 
Elzen, B., Geels, F.W., Hofman, P.S. and Green, K. (2004b) 'Socio-technical scenarios as a tool for transition policy: an example from the traffic and transport domain', System Innovation and the Transition to Sustainability: Theory, Evidence and Policy, pp.251-281, Edward Elgar Publishing, Cheltenham, UK/Northampton, MA, USA.

Farla, J., Markard, J., Raven, R. and Coenen, L. (2012) 'Sustainability transitions in the making: a closer look at actors, strategies and resources', Technological Forecasting and Social Change, Vol. 79, No. 6, pp.991-998.

Figenbaum, E., Assum, T. and Kolbenstvedt, M. (2015) 'Electromobility in Norway: experiences and opportunities', Research in Transportation Economics, Vol. 50, pp.29-38, DOI: https://doi.org/10.1016/j.retrec.2015.06.004.

Firnkorn, J. and Müller, M. (2011) 'What will be the environmental effects of new free-floating car-sharing systems? The case of car2go in Ulm', Ecological Economics, Vol. 70, No. 8, pp.1519-1528, DOI: https://doi.org/10.1016/j.ecolecon.2011.03.014.

Frenken, K. and Schor, J. (2017) 'Putting the sharing economy into perspective', Environmental Innovation and Societal Transitions, Vol. 23, pp.3-10, DOI: https://doi.org/10.1016/j.eist. 2017.01.003.

Geels, F.W. (2002) 'Technological transitions as evolutionary reconfiguration processes: a multi-level perspective and a case-study', Research Policy, Vol. 31, No. 8, pp.1257-1274, DOI: http://dx.doi.org/10.1016/S0048-7333(02)00062-8.

Geels, F.W. (2004) 'From sectoral systems of innovation to socio-technical systems', Research Policy, Vol. 33, No. 6, pp.897-920, DOI: http://dx.doi.org/10.1016/j.respol.2004.01.015.

Geels, F.W. (2011) 'The multi-level perspective on sustainability transitions: responses to seven criticisms', Environmental Innovation and Societal Transitions, Vol. 1, No. 1, pp.24-40, DOI: 10.1016/j.eist.2011.02.002.

Geels, F.W. (2012) 'A socio-technical analysis of low-carbon transitions: introducing the multi-level perspective into transport studies', Journal of Transport Geography, Vol. 24, pp.471-482, DOI: https://doi.org/10.1016/j.jtrangeo.2012.01.021.

Geels, F.W. (2017) 'Disruption and low-carbon system transformation: progress and new challenges in socio-technical transitions research and the multi-level perspective', Energy Research \& Social Science, DOI: https://doi.org/10.1016/j.erss.2017.10.010.

Geels, F.W. and Schot, J. (2007) 'Typology of sociotechnical transition pathways', Research Policy, Vol. 36, No. 3, pp.399-417, DOI: https://doi.org/10.1016/j.respol.2007.01.003.

Geels, F.W., Kern, F., Fuchs, G., Hinderer, N., Kungl, G., Mylan, J. and Wassermann, S. (2016) 'The enactment of socio-technical transition pathways: a reformulated typology and a comparative multi-level analysis of the German and UK low-carbon electricity transitions (1990-2014)', Research Policy, Vol. 45, No. 4, pp.896-913, DOI: 10.1016/j.respol.2016. 01.015 .

Geels, F.W., McMeekin, A., Mylan, J. and Southerton, D. (2015) 'A critical appraisal of sustainable consumption and production research: the reformist, revolutionary and reconfiguration positions', Global Environmental Change, Vol. 34, pp.1-12, DOI: 10.1016/ j.gloenvcha.2015.04.013.

George, C. and Julsrud, T.E. (2018) The Development of Organised Car Sharing in Norway: 1995-2018, ТØI Report 1663/2018.

Hildermeier, J. and Villareal, A. (2014) 'Two ways of defining sustainable mobility: Autolib' and BeMobility', Journal of Environmental Policy \& Planning, Vol. 16, No. 3, pp.321-336, DOI: 10.1080/1523908X.2014.880336.

Hodson, M., Geels, F. and McMeekin, A. (2017) 'Reconfiguring urban sustainability transitions, analysing multiplicity', Sustainability, Vol. 9, No. 2, p.299, DOI: https://doi.org/10.3390/ su9020299.

Kent, J., Dowling, R. and Maalsen, S. (2017) 'Catalysts for transport transitions: bridging the gap between disruptions and change', Journal of Transport Geography, Vol. 60, pp.200-207, DOI: https://doi.org/10.1016/j.jtrangeo.2017.03.013. 
Kent, J.L. and Dowling, R. (2016) “'Over 1000 cars and no garage': how urban planning supports car (park) sharing', Urban Policy and Research, Vol. 34, No. 3, pp.256-268, DOI: https://doi.org/10.1080/08111146.2015.1077806.

Kent, J.L. and Dowling, R. (2018) 'Commercial car sharing, complaints and coping: does sharing need willingness?', Urban Policy and Research, pp.1-12, DOI: https://doi.org/10.1080/ 08111146.2018.1486297.

Köhler, J., Geels, F., Kern, F., Onsongo, E. and Wieczorek, A. (2017) A Research Agenda for the Sustainability Transitions Research Network, Sustainable Consumption Institute, University of Manchester: Manchester, UK.

Kvale, S. (2007) Doing Interviews [online] http://methods.sagepub.com/book/doing-interviews DOI: $10.4135 / 9781849208963$.

Lanzini, P. (2018) 'The automotive industry and the increasing relevance of a consumer perspective: a research agenda', International Journal of Automotive Technology and Management, Vol. 18, No. 1, pp.46-58.

Lindloff, K., Pieper, N., Bandelow, N.C. and Woisetschläger, D.M. (2014) 'Drivers of carsharing diffusion in Germany: an actor-centred approach', International Journal of Automotive Technology and Management, Vol. 14, Nos. 3-4, pp.217-245, DOI: https://doi.org/10.1504/ IJATM.2014.065291.

Loorbach, D., Frantzeskaki, N. and Avelino, F. (2017) 'Sustainability transitions research: transforming science and practice for societal change', Annual Review of Environment and Resources, Vol. 42, pp.599-626.

Markard, J., Raven, R. and Truffer, B. (2012) 'Sustainability transitions: an emerging field of research and its prospects', Research Policy, Vol. 41, No. 6, pp.955-967, DOI: https://doi.org/ 10.1016/j.respol.2012.02.013.

Martin, C.J. (2016) 'The sharing economy: a pathway to sustainability or a nightmarish form of neoliberal capitalism?', Ecological Economics, Vol. 121, pp.149-159, DOI: https://doi.org/ 10.1016/j.ecolecon.2015.11.027.

Meijkamp, R. (1998) 'Changing consumer behaviour through eco-efficient services: an empirical study of car sharing in the Netherlands', Business Strategy and the Environment, Vol. 7, No. 4, pp.234-244, DOI: https://doi.org/10.1002/(SICI)1099-0836(199809)7:4<234::AIDBSE159>3.0.CO;2-A.

Miles, M.B., Huberman, A.M. and Saldana, J. (2013) Qualitative Data Analysis: a Methods Sourcebook, Sage Publications, Arizona State University, USA.

Næss, P. and Vogel, N. (2012) 'Sustainable urban development and the multi-level transition perspective', Environmental Innovation and Societal Transitions, Vol. 4, pp.36-50, DOI: http://dx.doi.org/10.1016/j.eist.2012.07.001.

Nykvist, B. and Whitmarsh, L. (2008) 'A multi-level analysis of sustainable mobility transitions: niche development in the UK and Sweden', Technological Forecasting and Social Change, Vol. 75, No. 9, pp.1373-1387, DOI: https://doi.org/10.1016/j.techfore.2008.05.006.

O'Brien, K. and Sygna, L. (2013) 'Responding to climate change: the three spheres of transformation', Proceedings of Transformation in a Changing Climate, pp.19-21.

Oslo kommune ved Plan-og bygningsetaten (2015) Revidering av parkeringsnormer for bolig, ncering og offentlig tjenesteyting for Oslo commune, Bakgrunnsrapport til høring, Saksnr, 201516232.

Rabbitt, N. and Ghosh, B. (2016) 'Economic and environmental impacts of organised car sharing services: a case study of Ireland', Research in Transportation Economics, Vol. 57, pp.3-12, DOI: http://dx.doi.org/10.1016/j.retrec.2016.10.001.

Raven, R., Kern, F., Verhees, B. and Smith, A. (2016) 'Niche construction and empowerment through socio-political work. A meta-analysis of six low-carbon technology cases', Environmental Innovation and Societal Transitions, Vol. 18, pp.164-180, DOI: https://doi.org /10.1016/j.eist.2015.02.002. 
Shaheen, S.A. and Cohen, A.P. (2013) 'Carsharing and personal vehicle services: worldwide market developments and emerging trends', International Journal of Sustainable Transportation, Vol. 7, No. 1, pp.5-34, DOI: https://doi.org/10.1080/15568318.2012.660103.

Sovacool, B.K. and Axsen, J. (2018) 'Functional, symbolic and societal frames for automobility: implications for sustainability transitions', Transportation Research Part A: Policy and Practice, Vol. 118, pp.730-746, DOI: https://doi.org/10.1016/j.tra.2018.10.008.

Temenos, C., Nikolaeva, A., Schwanen, T., Cresswell, T., Sengers, F., Watson, M. and Sheller, M. (2017) 'Theorizing mobility transitions: an interdisciplinary conversation', Transfers, Vol. 7, No. 1, pp.113-129, DOI: https://doi.org/10.3167/TRANS.2017.070109.

Tinnilä, M. and Kallio, J. (2015) 'Impact of future trends on personal mobility services', International Journal of Automotive Technology and Management, Vol. 15, No. 4, pp.401-417, DOI: https://doi.org/10.1504/IJATM.2015.072876.

Tobiassen, M. (2017) 'Jeg tror vi bare er i starten av noe som blir veldig stort', $D N$, 11 September [online] https://www.dn.no/handel/delingsokonomi/miklagruppen/even-heggernes/-jeg-tror-vibare-er-i-starten-av-noe-som-blir-veldig-stort/2-1-161218.

Truffer, B. (2003) 'User-led innovation processes: the development of professional car sharing by environmentally concerned citizens', Innovation: The European Journal of Social Science Research, Vol. 16, No. 2, pp.139-154, DOI: 10.1080/13511610304517.

Truffer, B., Schippl, J. and Fleischer, T. (2017) 'Decentering technology in technology assessment: prospects for socio-technical transitions in electric mobility in Germany', Technological Forecasting and Social Change, Vol. 122, pp.34-48, DOI: http://dx.doi.org/10.1016/ j.techfore.2017.04.020.

Urry, J. (2004) 'The 'system' of automobility', Theory, Culture \& Society, Vol. 21, Nos. 4-5, pp.25-39, DOI: https://doi.org/10.1177/0263276404046059.

Vervaeke, M. and Calabrese, G. (2015) 'Prospective design in the automotive sector and the trajectory of the Bluecar project: an electric car sharing system', International Journal of Vehicle Design, Vol. 68, No. 4, pp.245-264, DOI: https://doi.org/10.1504/IJVD.2015.071083.

Yilmaz, K. (2013) 'Comparison of quantitative and qualitative research traditions: epistemological, theoretical, and methodological differences', European Journal of Education, Vol. 48, No. 2, pp.311-325, DOI: https://doi.org/10.1111/ejed.12014.

Yin, R.K. (2010) Qualitative Research from Start to Finish, Guilford Press, New York, USA. 


\section{Appendix}

Table A1 Data collection overview of households

\begin{tabular}{|c|c|c|}
\hline Household number and location & Car-sharing service & Household with or without children \\
\hline$\# 01$ Etterstad & B2C cooperative & No children \\
\hline \#20 Bygdøy Allé & $\mathrm{B} 2 \mathrm{C}$ cooperative & No children \\
\hline \#22 Sagene & $\mathrm{B} 2 \mathrm{C}$ cooperative & No children \\
\hline \#23 Schouterrassen & B2C cooperative & No children \\
\hline \#25 Tøyen, nr prison & B2C cooperative & No children \\
\hline \#26 Ensjø & $\mathrm{B} 2 \mathrm{C}$ cooperative & No children \\
\hline \#27 Sinsen west & $\mathrm{B} 2 \mathrm{C}$ cooperative & No children \\
\hline \#30 Bislett & B2C cooperative & No children \\
\hline \#36 Bogstadveien & $\mathrm{B} 2 \mathrm{C}$ cooperative & No children \\
\hline \#37 Solli plass & $\mathrm{B} 2 \mathrm{C}$ cooperative & No children \\
\hline \#39 Ruseløkka & $\mathrm{B} 2 \mathrm{C}$ cooperative & Children \\
\hline \#08 Storo & B2C cooperative & Children \\
\hline \#09 Sinsen & $\mathrm{B} 2 \mathrm{C}$ cooperative & Children \\
\hline \#13 Keyserløkka & $\mathrm{B} 2 \mathrm{C}$ cooperative & Children \\
\hline \#15 Ekeberg & $\mathrm{B} 2 \mathrm{C}$ cooperative & Children \\
\hline \#16 Tøyen & B2C cooperative & Children \\
\hline \#29 Vålerenga & $\mathrm{B} 2 \mathrm{C}$ cooperative & Children \\
\hline \#38 Hovseter & $\mathrm{B} 2 \mathrm{C}$ cooperative & Children \\
\hline \#05 Torshov & B2C corporate & No children \\
\hline \#06 Barcode & $\mathrm{B} 2 \mathrm{C}$ corporate & No children \\
\hline \#14 Ulven & $\mathrm{B} 2 \mathrm{C}$ corporate & No children \\
\hline \#17 Fornebu & $\mathrm{B} 2 \mathrm{C}$ corporate & No children \\
\hline \#31 Torshovparken & B2C corporate & No children \\
\hline \#33 Adamstuen & $\mathrm{B} 2 \mathrm{C}$ corporate & No children \\
\hline \#34 Kvadraturen & B2C corporate & No children \\
\hline \#04 Smedstad & $\mathrm{B} 2 \mathrm{C}$ corporate & Children \\
\hline \#07 Vika & $\mathrm{B} 2 \mathrm{C}$ corporate & Children \\
\hline \#21 Rosenhoff & B2C corporate & Children \\
\hline \#35 St Hanshaugen & $\mathrm{B} 2 \mathrm{C}$ corporate & Children \\
\hline \#03 Bøler & $\mathrm{P} 2 \mathrm{P}$ & No children \\
\hline \#11 Veitvet & $\mathrm{P} 2 \mathrm{P}$ & No children \\
\hline \#12 Pilestredet & $\mathrm{P} 2 \mathrm{P}$ & No children \\
\hline \#19 Grünerløkka (lower) & $\mathrm{P} 2 \mathrm{P}$ & No children \\
\hline \#24 Høybråten & $\mathrm{P} 2 \mathrm{P}$ & No children \\
\hline \#28 Årvoll & $\mathrm{P} 2 \mathrm{P}$ & Children \\
\hline \#02 Carl Berner & $\mathrm{P} 2 \mathrm{P}$ & Children \\
\hline \#10 Manglerud & $\mathrm{P} 2 \mathrm{P}$ & Children \\
\hline \#18 Nesodden & $\mathrm{P} 2 \mathrm{P}$ & Children \\
\hline \#32 Kampen & $\mathrm{P} 2 \mathrm{P}$ & Children \\
\hline
\end{tabular}


Table A2 Interview guide

1 Introduction

Interviewer explains about the interview (the project, main themes for interview, length, anticipated use of results etc.).

Gives information about confidentiality and privacy (and confidentiality statement if applicable).

Asks permission to use tape recorder.

Incentives gift card for participation.

2 Life situation

Could you please tell us a bit about the 'story' of your household? (Life course, important choices, cohabitation, relocation, childbirth etc.)

How would you describe your life situation at present? (Recent changes in life course, etc.)

Have any recent changes in life course changed how you travel on a daily basis?

Main daytime occupations of household members? (Work, school, studies, etc.)

Are any members of the household involved in leisure activities that require transport?

Do you have family and friends living close by, or do they live farther away?

3 Daily travel

What kind of transport resources does the household have access to? (Cars, shared cars, bikes, public transport, etc.)

Could you describe your household travel patterns on a typical day (e.g., yesterday)?

(Purpose, destination, transport mode, shared transport resources, etc.)

Have there been any important changes in these travel routines during the past year?

How do you view your daily travel - are you satisfied/are there things that create stress, or on the contrary that work well?

4 Leisure travel

What kinds of leisure trips do members of your household make - travel not connected with work or school, etc., (ref. answers about daily travel above).

What kinds of holiday or weekend trips do you make? Please tell us about, for instance, your latest overnight trip.

What kind of transport do you use for such holiday/weekend trips?

5 Motivation

Can you tell us about the background for why you started using car sharing? (Motives, household discussions, specific events/experiences, etc.)

What were your experiences with (regular) car use before you started using car sharing? Were there specific events or conditions that influenced your decision to start using car sharing?

How did you get to know about this car-sharing arrangement? (Friends, colleagues, media, social media, etc.)

Do you know other households that use car sharing?

Are you familiar with any other car-sharing arrangements? (Mention a few main alternatives: P2P, B2C etc.)

Have you considered any alternative car-sharing arrangements? (Why/why not?) 
Table A2 Interview guide (continued)

$6 \quad$ Practical elements

How and when does your household use car sharing? (Frequency, users, purpose/situation, etc.)

How do you use car sharing in combination with other means of transportation? (Public transport, bikes, other cars, etc.)

Could you tell us a bit about the last time you used car sharing? (Materials, technology use etc.: materials can be the car itself/type, equipment like child seats, parking arrangements, mobile phone app.)

How has it been, learning to use the car-share system (knowledge/skill barriers, necessary skills, e.g., use of the app or booking system, parking procedures, cost calculation and time planning).

What do you feel are the advantages of car-sharing arrangements? (Individual, societal, regional)

Does car sharing have any importance to you beyond cost saving? (Convenience, environment, resource use)

Do you think such car-sharing arrangements will be important in the future? (Will many more people adopt this practice/trend)

7 Implications

Would you prefer to continue living in the area you live now, or move elsewhere in the near future? (If so, where?)

What are your experiences after using this car-sharing arrangement? (Positive/negative/ general feelings)

Do you think car-sharing has changed your household's general mobility pattern? [e.g., fewer trips, fewer (unnecessary) car trips, more use of home office, shorter/fewer holiday trips, fewer family/friend visits, etc., or more such travel]

What of sharing other things than cars - have you done that lately? (e.g., holiday apartments, cabins, tools and equipment, food/foodservice, second-hand trade, eBay, etc.)

Looking 5-6 years ahead, do you think your household will still use car sharing? (Why/why not?)

Are there any incentives or facilitators that would increase your use of car sharing? (e.g., dedicated parking, access to car-pool lanes, subsidies/lower cost, more/better access to shared cars/more locations, etc.) 